\title{
Vegetarian food recommendation in the traditional Islamic teachings to increase the fertility of men
}

\author{
Reza Dehghani Bidgoli
}

\begin{abstract}
About half of the infertilities are due to men's problems. In medicine, there are valuable treasures that confirm the effectiveness of some of them today and they have been approved for the treatment of diseases. The purpose of this paper is to investigate the drug's advice in increasing the fertility of men in Muslim narrative texts and compare it with new knowledge of humanity in medicine. For this purpose, we searched the fertility, men, and vegetable food keywords in the database and valid Islamic books and presented them in this article. Also, the results of academic research have also been pointed out to confirm these religious teachings. Some of the issues in traditional Islamic teachings that have been expressed centuries ago have been confirmed by modern medical science and have been the basis of making effective drugs for treating male infertility. Some of them also need further research. According to the emphasis of available Islamic traditional medicine from the infallible on the efficacy of the vegetable food in improving the quality of the seminal fluid and also confirming the usefulness in clinical trials, these plants can be useful in increasing fertility.
\end{abstract}

Keywords: Infertility, Men, Medical narrations, Religious teachings

\section{Introduction}

Infertility is a disability in embryo production after one year of intercourse, without using any contraceptive method. About $8 \%$ of couples in Iran are suffering from this problem [1]. Approximately half of these infertilities in men can be for various reasons such as chromosomal aberration, gene mutation, Infectious diseases, varicocele, chronic obstruction, chemotherapy, and radiation $[2,3]$. In the infertile men's semen analysis, we can see a decline in the quality of sperm which means a reduction in the number and mobility or proportion of morphology of normal sperm [4].

Infertility is a phenomenon that has been mixed up with human life for a long time. It is also mentioned in the scripture including the story of Prophet Abraham and his wife Sarah [5]. On the other hand, now, the interest in and treatment with medicinal plants in the prevention and treatment of diseases have been welcomed. In medical narratives, the valuable prescription

Correspondence: dehghanir@kashanu.ac.ir

Department of Rangeland and Watershed Management, Faculty of Natural

Resources and Earth Sciences, University of Kashan, Kashan 87317-53153, Iran using medicinal plants for preservation of health, prevention, and treatment of diseases is recommended (Fig. 1).

The religion of Islam has one of the most comprehensive eating and dietary habits and one even wonders as to why all the strict rulings. This is true because the stomach is one of those bodily organs that is largely unstable in electrical terms and when there is over-eating or there is junk food ingested, this over-stresses the stomach and the organs concerned with digestion become chemically and electrically at fault $[6,7]$. The resulting faults in the surrounding energy would not only cause alimentary and digestive disorders, but also mental disorders. Such a person would have weak and low charge energy surrounding him, making him more vulnerable to unsteady fields of energy [8].

The food one eats has a great impact not only on the physical aspect of a person but also on the soul and psyche as well. Therefore, it is strongly recommended that parents-to-be stay away from forbidden food and even the food which is doubtful. Additionally, some foods have also been specifically recommended by the Imams for a beautiful and righteous child [9].

(C) The Author(s). 2019 Open Access This article is distributed under the terms of the Creative Commons Attribution 4.0 International License (http://creativecommons.org/licenses/by/4.0/), which permits unrestricted use, distribution, and reproduction in any medium, provided you give appropriate credit to the original author(s) and the source, provide a link to the Creative Commons license, and indicate if changes were made. The Creative Commons Public Domain Dedication waiver (http://creativecommons.org/publicdomain/zero/1.0/) applies to the data made available in this article, unless otherwise stated. 


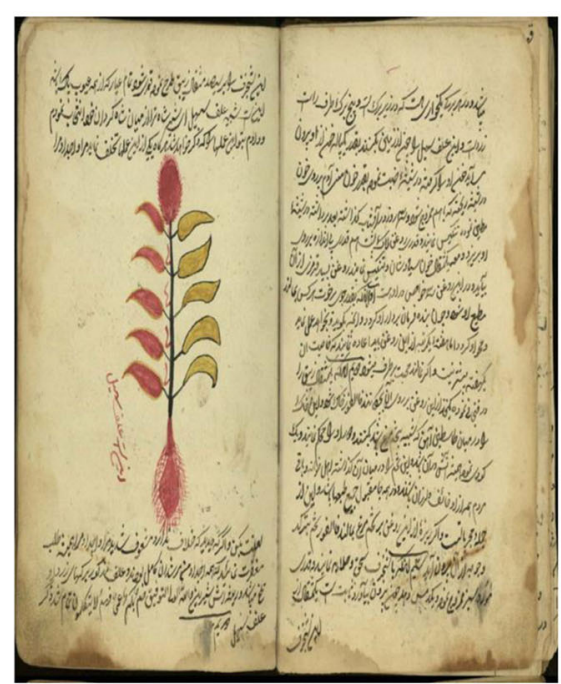

(b)

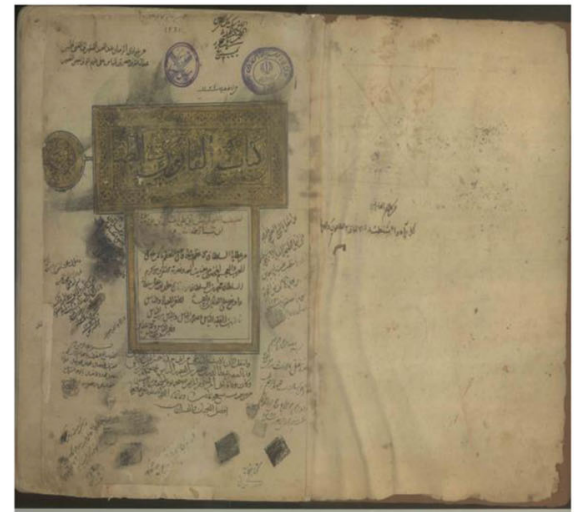

(c)

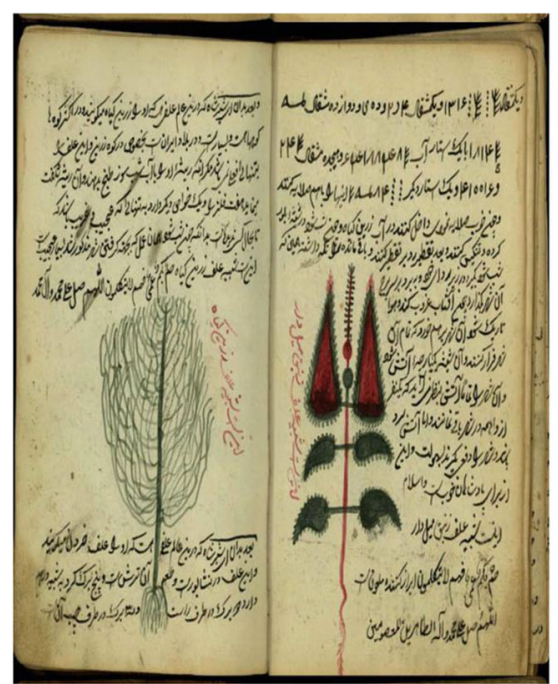

(a)

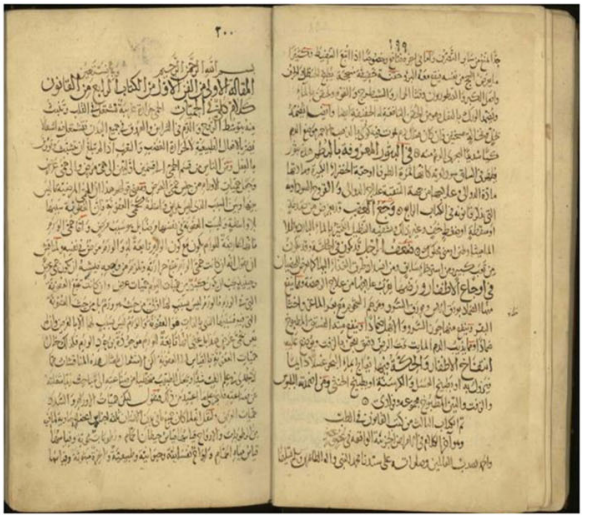

(d)

Fig. 1 Male infertility from the perspective of traditional Islamic medicine, its causes, and its remedies. a Al-Hawi, Muhammad ibn Zakariya al-Razi,10th century, which is known in Europe also as "The Large Comprehensive" or "Continens Liber (Jameh-al-Kabir)." This book contains considerations in various medical subjects and also criticisms on Greek and Aristotelian concepts. Al-Razi stated in this treatises "My aim and objective is [to provide] things useful to people who practice and work, not for those engaged in research and theory" Chap5 (pp. 112-13). This work expresses many innovative views, and thus, many scholars consider Rhazes the greatest physician of the Middle Ages. b Zakhireye Khwarazmshahi, Ismail Gorgani, 1110 Arabic. This persian medical book is equal in prestige to the famous medical book by Avicenna, which is considered medical canon. In chapter ten, he writes about the classification of drugs and basic pharmacology. The plants in nature which happen to be spread ubiquitously have fewer side effects, have stood the test of time by being buttressed through scientific experiments, and have been the cynosure of attention among people; therefore, they can be of great help in this regard. c The Canon of Medicine (al-Qanun fi al-Tibb), Avicenna (Ibn Sina). The Canon of Medicine is an encyclopedia of medicine in five books compiled by Persian Muslim physician-philosopher Avicenna and completed in 1025. This book was translated into Latin towards the end of the twelfth century $C E$, and became a reference source for medical studies in the universities of Europe until the end of the seventeenth century. d Avicenna and "Ibn Sina". Avicenna described various uses of the plant, including its use as a treatment for sexual and perversions diseases, infertility, inducer of labor, and others. Most of these effects have been studied in modern pharmacology and are well documented

The below story has been mentioned in authentic Shiite books such as Hilyat al-Muttaqin by Mohammad-Baqer Majlesi and Wasail al-Shia by Al-Hurr al-Amili "Before the conception of Hazrat Fatima (sa), the Prophet Muhammad (S) by the command of Allah (SwT) stayed away from his wife Hazrat Khadijah for 40 days and during these 40 days, he performed acts of worship and fasted, and his iftar consisted of food that had been brought from the heaven". This heavenly meal consisted of a bunch of fresh dates and a bunch of grapes [10].

According to this authentic hadith, it is important for Muslims to eat certain foods, especially vegetarian foods before sexual intercourse. Also, the other narrative references have recommended dates and grapes for men from the 
beginning of maturity while these two vegetarian food have the best sugars that are needed to make sperm and improve the quality of it [11].

According to Imam Ja'far-e-Sadiq (a.s.), Sattu (a blend of cereal powder or flour) was made with reference to a revelation from God. It increases weight, strengthens bones, and is the food of Prophets. Dry sattu cleans and diminishes white spots and, when had with olive oil, increases weight, strengthens bones, and freshens complexion and increases sexual strength; if three tablespoons of sattu are taken in the morning, then it cures phlegm and cholera (i.e., Balgham and Safra) $[12,13]$.

According to a reliable tradition from Imam Reza (a.s.), fig cleans bad smell of the mouth, strengthens bones, increases hair, and cures different types of pains. One does not need any medicine after having figs. Among all the fruits, the fig has close similarity with the fruits of heaven. It also cures colic (qulanj). It is also stated that figs cure piles and pain in toes and fingers of the legs. It increases sexual strength [14].

Today, the effectiveness of some of them has been confirmed. According to the search that we did, so far, the treatments available in Muslims medical narratives for men's infertility with our present knowledge in medical science have not been compared. Therefore, the purpose of this article is introducing the most common herbal remedies for men's infertility among Muslims according to their narrative medicine and comparing ethnic knowledge with modern medical knowledge.

\section{Materials and methods}

This study was conducted using a library method. In this regard, the most common and most consumed plant food in Muslim societies, such as the onion and pomegranate, and men's infertility keywords were searched in databases and search engines like PubMed and Google scholar and in the holy and popular books of Muslims like Teb-AlKabir, Makarm-Alakhlagh, and Baharolanvar; then, the related content of sexual disability, sexual dysfunction, and seminal fluid was investigated, and finally, we did a comparative comparison for these Islamic religious narratives with results of new medical science.

\section{Results and discussion Pomegranate}

The pomegranate is one of the fruits which is mentioned in the Islamic medical narratives to increase seminal fluid. Prophet Muhammad (peace be upon him (PBUH)) has said: "Eating the pomegranates increases the amount of seminal production and feeding it by men before sexual intercourse will make her child beautiful." [2]. Also, Imam Reza eighth Shiite (Shia) leader has said: "eating of sweet pomegranates enhances the men's sexual force leads to the beauty of the child" [15]. The recent researches show that Pomegranate consumption improves the quality of sperm (number, motility, percentage, and natural morphology of the sperm) $[16,17]$. Templeton (1995) reported that prescribing a suitable amount of pomegranate extract improved the quality of sperm [18].

\section{Onion (Allium cepa)}

The onion is another plant mentioned in the verses and hadiths of Islam religion. This 2-year plant with the scientific name Allium cepa has a variety of ingredients such as E, $B_{1}, B_{2}, B_{6}, C$ vitamins and Biotin, Pectin, Lectin, Quercetin, Prostaglandin, and other fatty acids which in the medical narratives have been mentioned for this plant as having several therapeutic properties [19].

Imam Ja'far Sadiq sixth Shiite (Shia) leader has said about it "Eat onion because there are three benefits for the onion: it makes your mouth fragrant, tightens the gum and increases the amount of semen and sexual intercourse" [9]. The results of the study by Nikravesh et al. showed that the prescribing of onion extract improves the spermatogenesis process [10].

Khaki et al. in their study showed the protective role of onion extract in the biological activity of the human reproduction machine. Also, Kikelomo et al. (2008) used the onion extract to neutralize the toxic effects contaminating agents the testicular structure and improve the spermatogenesis process $[10,13]$.

\section{Cydonia oblonga Miller}

Imam Ja'far Sadiq, sixth Shiite (Shia) leader, has said "Eating this fruit in fasting condition leads to strengthening seminal fluid" [15]. Amini Rad et al. (2011) in a study indicated that using the extract of this fruit increases sexual activity and fertility potential [20].

\section{Melon and carrot}

A study that was conducted on the 200 healthy men under the diet of fruits and vegetables indicated (Cucumis melo L) and (Daucus carota subsp. Sativus) increases the quality and quantity of sperm, especially the carotenoids in carrots which have a positive effect on motility and progressive forward movement of sperm [11, 21].

Muslim religious recommendations also refer to the use of these two plants. For example, Prophet Mohammad (PBUH) has said about the properties of melon. "Eat melon, because it has ten qualities" Melon is food, water, freshener, and cleaner. This plant cleans the bladder, cleans the stomach, and cleans the skin; it also increases semen and increases the power of sexual intercourse. Eating this fruit decreases mal-temperament". The seventh leader of the Shi'a (Imam Musa Kazim) also has said about eating carrots: "Carrots heat the kidneys and complete the erection in men." [8]. 


\section{Thymus and cyprus}

The sixth leader of the Shi'a (Imam Sadiq) recommended the use of thymus with salt, for treatment of male sexual discomfort and has said "Use Saad (Cyperus rotundus L) between your teeth, because, it makes your mouth fragrant and increase to the power of sexual intercourse."

\section{Meat, eggs, and dates}

Prophet Muhammad (PBUH) also has said that eating dates and meat is an enhancer of sexual power and has said "Eating egg with meat increase the men's sexual power".

\section{Pumpkin and lentil}

Prophet Muhammad (PBUH) has said about eating Pumpkin and lentils: Everyone consumes pumpkin with lentils while telling God's name, his heart will calm down and his sexual intercourse power will be an increase $[13,22]$.

\section{Savigh, fig, and chicory}

The sixth Shiite leader (Imam Sadiq) has said: "Eating of savigh (mixed of 40 seeds powder of medicinal herbs such as sesame, Nigella Sativa, Portulaca and etc.) with olive oil, because it causes men to become obese and tightens the bone and Increases the power of sexual intercourse" [15, 23].

Prophet Mohammad (PBUH) also has said that "Eating fresh and dry figs, increases the power of sexual intercourse" $[9,11]$.

In the case of Chicory, the sixth Shia leader (Imam Sadiq) has said "Eating chicory increases semen, this plant is warm and laxative, and eating it increases the number of males' infants" [8]. The results a study (BehnamRassouli et al., 2010) showed using aqueous extract of chicory in pregnant women increased the number of male infants compared to female infants [11].

Finally, we refer to Sodab (Ruta graveolens from Rutaceae) which is a bush and branching branch plant with yellow flowers. Imam Reza (the eighth leader of the Shiites) has said about this plant "Sodab, causing an increase of wisdom and decreasing of semen." This plant reduces sexual desire and decreases testosterone levels (FSH) and fertility in men [3, 24].

The researchers believe that this plant's effect is related to the effect of the coumarin of this plant on sperm potassium channels. Also, some researchers believe the mechanism of this effect in Sodab is due to its effect on the hypothalamic-pituitary axis. Finally, it is necessary to explain that the citations and resources used in this article are not part of the first-hand resources; that is one of the limitations of this research. Proven effects in laboratory studies with the effects mentioned in Muslim religious texts are explained in the (Table 1).
The following mentioned the other recommended foods before trying to conceive. Although Muslim women are now consuming these foods before pregnancy, these foods are mostly recommended for strengthening men's sexual power, such as erectile strength.

\section{Qawoot}

Qawoot is as follows:

a. Qawoot is a powder made by grinding and sifting the following ingredients in relative quantities: roasted wheat, roasted barley, roasted sun-flower seeds, roasted watermelon seeds, roasted melon seeds, roasted deep ribbed melon seeds, roasted purslane seeds, roasted coriander, roasted hemp-seeds, roasted fennel seeds, roasted poppy seeds, roasted peas, sesame, pistachio, coffee, cardamom, cinnamon, almond, and sugar [25].

As this mixture is not readily available in most countries, it is suggested that the above contents are eaten on their own, e.g., pistachios and almonds.

b. It has been recommended that both the father and mother should eat qawoot:

It is narrated that a man told Imam as-Sadiq (as): "O son of the Messenger of Allah (SwT), a son has just been born who is weak and simple-minded." Imam replied: "Why didn't you eat qawoot? Eat that and recommend your family to do so too. Surely, qawoot makes flesh grow and makes the bones firm, and a son will not be born from you except that he is strong." [26, 27].

c. It is narrated from Imam as-Sadiq (as): "Eating qawoot with olive oil and meat fattens a person, makes bones firm, makes the body bright and with Nür (Noble light) and increases the sexual power."

\section{Quince}

Quince is as follows:

a. It is narrated that Imam as-Sadiq (as) saw a beautiful child and said, "It is very likely that the father of this child ate the fruit quince on the night of conception."

b. It is also narrated from him that: "Eating (quince on the night of conception) makes the face (of the foetus) beautiful and good, and the heart strong and firm." [28].

c. Another tradition from Imam as-Sadiq (as) narrates "Anyone who eats quince on an empty stomach, the source of his sex fluid (sperm) becomes pure and healthy, and his child will be beautiful and decent." [29].

d. It is narrated that the Muhammad (S) cut his quince into pieces and gave one to Jafar ibn Abi 
Table 1 Comparing the effects of some of medicinal plants on the male fertility in Islamic religious recommendations and medical science findings

\begin{tabular}{|c|c|c|}
\hline $\begin{array}{c}\text { Proven effects in laboratory } \\
\text { studies }\end{array}$ & Plant name & $\begin{array}{l}\text { The effects mentioned in } \\
\text { Muslim religious texts }\end{array}$ \\
\hline $\begin{array}{l}\text { 1.Have antioxidant compounds } \\
\text { 2.Removed Free radical } \\
\text { 3.Increasing the quality sperm } \\
\text { And the number of births }\end{array}$ & & $\begin{array}{l}\text { Increasing semen }+ \text { Increasing the } \\
\text { power of sexual intercourse }\end{array}$ \\
\hline $\begin{array}{l}\text { 1.Have antioxidant compounds } \\
\text { 2.Removed Free radical } \\
\text { 3.Improvement spermatogenesis }\end{array}$ & & $\begin{array}{l}\text { Increasing semen }+ \text { Increasing the } \\
\text { power of sexual intercourse }+ \\
\text { Increasing Sexual desire }\end{array}$ \\
\hline $\begin{array}{l}\text { 1.Have antioxidant compounds } \\
\text { 2.Removed Free radical } \\
\text { 3. Increasing the power of sexual } \\
\text { intercourse and fertility potential }\end{array}$ & & Increasing semen \\
\hline $\begin{array}{l}\text { 1.Have antioxidant compounds } \\
\text { 2.Removed Free radical } \\
\text { 3.Increasing the quality sperm }\end{array}$ & & $\begin{array}{l}\text { Increasing semen }+ \text { Increasing the } \\
\text { power of sexual intercourse }\end{array}$ \\
\hline $\begin{array}{l}\text { 1. Have Carotenoids } \\
\text { 2.Removed Free radical } \\
\text { 3.Increasing the quality sperm }\end{array}$ & & Full erection \\
\hline $\begin{array}{l}\text { 1.Have antioxidant compounds } \\
\text { 2. Increasing Sexual desire }\end{array}$ & & Full erection \\
\hline $\begin{array}{l}\text { 1. Increasing the power of sexual } \\
\text { intercourse }\end{array}$ & & $\begin{array}{l}\text { Increasing the power of sexual } \\
\text { intercourse }\end{array}$ \\
\hline N/A & & $\begin{array}{l}\text { Increasing the power of sexual } \\
\text { intercourse+ Increasing Sexual } \\
\text { desire }\end{array}$ \\
\hline $\begin{array}{l}\text { 1.Have antioxidant compounds } \\
\text { 2.Improvement spermatogenesis }\end{array}$ & & $\begin{array}{l}\text { Increasing the power of sexual } \\
\text { intercourse }\end{array}$ \\
\hline $\mathrm{N} / \mathrm{A}$ & & Increasing the power of sexual intercourse \\
\hline
\end{tabular}


Talib and told him: "Eat! This quince gives luster your face and makes the child good" [30].

\section{Conclusion}

The search in the scientific resources shows that there is a lot of medical knowledge that has been proven over time, while it was mentioned centuries ago in the Quran or the recommendations of Muslim religious leaders. These references, such as Teb-Alreza and Teb-Alsadeq have been used by some medical leaders such as Abu Ali Sina (Ibn Sina). Although many of these cases require laboratory testing, it is quite clear that the value of these recommendations is not less than the recommendations of Socrates and Hippocrates.

We did not find any study on the effects of meat, lentil, and pumpkin consumption on men's fertility or on the quality and quantity of the sperm. So investigating this issue is recommended to researchers. Today, it should be acknowledged that traditional medicine can serve as a useful tool in the service of new medical science, perhaps it could be a good solution to some of the chronic diseases.

The instructions about prevention and treatment of male infertility that are mentioned in the valuable resources including hadiths and Muslim narrations are based on the medicinal plants. These medicinal plants do not have the possible negative effects of chemical drugs and due to the climatic conditions in Iran, it is easily available. It seems, with the view of the emphasis on religious practices regarding the effectiveness of medicinal plants in the treatment of men infertility and the proof of the usefulness of these plants in the new research, the placement of these plants in the diet of men who suffer from impotence can be helpful along with other treatments.

Undoubtedly one of the major causes of divorce in human societies is women's dissatisfaction with men's sexual power. The author believes that by incorporating these valuable, low-risk, and somewhat inexpensive foods in the diet, while increasing men's health and sexual power, we can hope to reduce the divorce rate.

\section{Abbreviation \\ PBUH: Peace be upon him}

\section{Acknowledgements}

The author wish to thank the University of Kashan for supporting this research.

\section{Authors' contributions}

All authors read and approved the final manuscript.

\section{Funding}

This project supported by University of Kashan, Iran.

\section{Availability of data and materials}

Not applicable

Ethics approval and consent to participate

The author is fully satisfied with this project and its publication.

\section{Consent for publication}

The author agrees to publish this article.

\section{Competing interests}

The author declares that there are no competing interests.

\section{Received: 18 May 2019 Accepted: 12 September 2019}

\section{- 20.00}

\section{References}

1. Ahmadi A, Nasirizadeh F, Parivar K. Effect of aqueous extract of the aerial part of the Ruta graveolens on the spermatogenesis of immature balb/c mice. J Med Scie. 2007:14(56):13e20.

2. Nasr-Esfahani MH, Tavalaee M. Sperm. First reprint. 2th ed. Tehran: Royan institute; 2012. p. 150e180

3. Türk G, Sönmez M, Aydin M, Yüce A, Gür S, Yüksel M, et al. Effects of pomegranate juice consumption on sperm quality, spermatogenic cell density, antioxidant activity and testosterone level in male rats. J Clin Nutr. 2008:27:289e296.

4. Akhtari E, Bioos S, Sohrabvand F. Infertility in Iranian traditional medicine from Hakim Mohammad Azam Khan point of view. Iran J Obstet Gynecol Infertil. 2015;18(148):23e18.

5. Islami Hosseini SA. Holy medicine with traditional medicine. 4th ed. Tehran: Quran s bostan publications; 2011. p. 256e268.

6. Ola-Mudathir KF, Suru SM, Fafunso MA, Obioha UE, Toyin Y. Protective roles of onion and garlic extracts on cadmium-induced changes in sperm characteristics and testicular oxidative damage in rats. J Food and chemical Tocxicol. 2008:46:3604e3611.

7. Nikravesh R, Jalali M, Mohammadi SH. Effects of crude onion extract on murine testis. J Reprod Infertil. 2010;10(4):239e244.

8. Safarinejad MR. Infertility among couples in a population-based study in Iran: prevalence and associated risk factors. Int J Androl. 2008;31(3):303e313.

9. Tbarsi H. Makarem alakhlagh. 5th ed. Qom: Sharif Razi Publication; 1990. p. 177 e344

10. Templeton A. Infertility-epidemiology, aetiology and effective management. Health Bull (Edinb). 1995;53:294e298.

11. Tibb-e-Albagher AL, Rashedi S. Pour saeb publications, Tehran. 5th ed: 2011. p. 280e295

12. Razi B. Kholasato-tajarob. Tehran: The School of Traditional Iranian Medicine; 2007. (Persian)

13. Sailani MR, Moeini H. Effect of Ruta graveolens and Cannabis sativa alcoholic extract on spermatogenesis in the adult wistar male rats. Indian J Urol. 2007;23(3):257e260.

14. Speroff L, Fritz MA. Clinical gynaecologic endocrinology and infertility. New York: Lippincott Williams \& Wilkins; 2005.

15. Muhammad Aslam A, Akbar S. Effect of hydro-alcoholic extract of cydonia oblonga miller on sexual behavoiur of wistar rats. J Advances in Pharmacological Scie. 2014:3:6e20 https://doi.org/10.1155/2014/282698.

16. Behnam-Rassouli M, Aliakbarpour A, Hosseinzadeh H, Behnam-Rassouli F, Chamsaz M. Investigating the effect of aqueous extract of Chicorium intybus L. Leaves on offspring sex ratio in Rat. J Phytother Res. 2010;24:1417e1421.

17. Majlisi MB. Bihar al-Anwar, vol. 66. 20th ed. Tehran: Vali asr publication; 1983. p. 80e297.

18. Amini Rad O, Khalili MA, Soltani Gord HR, Faramarzi HR. Influence of pomegranate juice on sperm parameters and fertility in mice. J Hormozgan. 2010;13(3):182e188.

19. Ibn Sina H. Kitab al Qanoun fi Al Toubb (The Book of the Canon of Medicine). Beirut: American University of Beirut; 2007.

20. Vahidi S, Ardalan A, Mohammad K. Prevalence of primary infertility in the Islamic Republic of Iran in 2004-2005. Asia Pac J Public Health. 2009;21(3):87e93.

21. Baker VL, Luke B, Brown MB, Alvero R, Frattarelli IL, Usadi R, et al. Multivariate analysis of factors affecting probability of pregnancy and live birth with in vitro fertilization: an analysis of the Society for Assisted Reproductive Technology Clinic Outcomes Reporting System. J Fertil Steril. 2010;94(4):406e-410.

22. Ibn-e-An-Nafis. Sharh Tashreeh Al-Qanun. 3th ed. Islamic Golden Age: Egypt; 2013. p. 266.

23. Barghi A, Almahasen Q. Dar Alketab Eslamieh, vol. 2. 10th ed; 1992. p. $313 e 356$.

24. Corzo-Mart M, Corzo N, Villamiel M. Biological properties of onions and garlic. J Trendsin food Scie \& Tech. 2007;18:609e625.

25. Gil-Guzman E, Ollero M, Lopez MC, Sharma RK, Alvarez JG, Thomas AJ Jr, et al. Differential production of reactive oxygen species by subsets of 
human spermatozoa at different stages of maturation. J Hum Reprod. 2001;16(9):1922e1930

26. Islami H, Holy SA. Medicine with traditional medicine. 5th ed. Tehran: Quran s bostan publications; 2011. p. 165e167.

27. Khaki A, Fathiazad F, Nouri M, Khaki AA, Khamenehi HJ, Hamadeh M. Evaluation of androgenic activity of allium cepa on spermatogenesis in the rat. Folia Morphol (Warsz). 2009;68(1):45e51.

28. Khouri NA, El-Akawi Z. Antiandrogenic activity of Ruta graveolens L. in male Albino rats with emphasis on sexual and aggressive behavior. J Neuro Endocrinol let. 2005;26(6):823e829.

29. Maretti C. Obesity and male infertility. In: Cavallini G, Beretta G, editors Clinical management of male infertility. Switzerland: Springer International Publishing; 2015. p. 89e97.

30. Mohamed A, Dkhil S, Al-Quraishy B, Moneim AEA. Effect of pomegranate (Punica granatum L.) juice and methanolic peel extract on testis of male rats. Pakistan J Zool. 2013;45(5):1343e1349,

\section{Publisher's Note}

Springer Nature remains neutral with regard to jurisdictional claims in published maps and institutional affiliations.

Ready to submit your research? Choose BMC and benefit from:

- fast, convenient online submission

- thorough peer review by experienced researchers in your field

- rapid publication on acceptance

- support for research data, including large and complex data types

- gold Open Access which fosters wider collaboration and increased citations

- maximum visibility for your research: over $100 \mathrm{M}$ website views per year

At BMC, research is always in progress.

Learn more biomedcentral.com/submissions 